\title{
Role of Academic and Public Libraries in Democracy
}

\author{
Manpreet $\operatorname{Kaur}^{1}$, Chandra Prakash Chaudhary ${ }^{2}$ \\ ${ }^{1}$ Assistant Librarian in Govind National College, Narangwal (Ludhiana) Punjab \\ ${ }^{2}$ Assistant Librarian, Panjab University Extension Library, Ludhiana (Punjab)
}

\begin{abstract}
Library is a heart of any academic institution. Without heart, we cannot assume the existence of any institution. Now-a-days academic libraries play very important role in Institutions as well as in community with the collaboration of public libraries. They are not only a hub of books but also known as information centre, where information is provided to the users related to their subject along with current issues. In democratic country library can play a drastic role to aware the users about democracy by organizing table discussion or debate.
\end{abstract}

Keywords: Democracy, Libraries, Academic libraries, Public libraries.

\section{INTRODUCTION}

Without libraries what do we have? We have no past and no future. Libraries are a store house of knowledge power. Now-a-days many libraries are engaged in knowledge management for providing the right information, to the right users, at the right time. In academic libraries librarian can engage the students as well as faculty members in many activities, which facilitate them to play active role in the society as well as for the nation because that country go upward, where citizens of nation are more active in productive activities. Energetic people make the country more active in progressive way.

\section{ROLE OF LIBRARIES IN DEMOCRACY}

College libraries can play the vital role to make the citizens more active, especially those students which are future of nation. Young people have ability to adjust them in any environment and change the environment according to the need of time. They have more power to think and formulate solution to any problem. So librarian can organize seminars, workshops, round table discussion about current issues which have more value to the society. For e.g. In India 'Swachh Bharat Abhiyan' is going on. It was launched by our honored Prime Minister Shri Narendra Modi on $2^{\text {nd }}$ October 2014. It was accepted by all the citizens of nation by cordially. Media played a very important role to circulate the same in respective societies, but those people who are illiterate do not bother about these things. To make them a part of nation academic libraries can organize a seminar with the collaboration of public libraries in rural areas to inform the people, how can they make a part of nation as well as can become a active participants of nation because nation is nothing itself, especially in democratic country. Nation forms with the active participation of people \& people make the nation. In democratic nation people choose the head of the nation by voting them. So people should be aware about their voting rights and they should know which party should be chosen to lead which will play the active role honestly to go forward the nation. Librarian can organize the table discussion to discuss the problem and to develop the thinking ability of the users. In discussion every participants have right to discuss their problem.

${ }^{1}$ S.R. Ranganathan (1892-1972): The purpose of education is releasing and exercising the creative ability of each member of the community in his own field and in his own measure. ${ }^{1}$

${ }^{2}$ The library is central to our free society. It is a critical element in the free exchange of information at the heart of our democracy. ${ }^{2}$ Library is a focal point of intellectual and literacy activities, which can play a fruitful role to mould the character and sharpening the thoughts of users.

\section{DEMOCRACY V/S ACADEMIC LIBRARIES}

Library is a knowledge circulating centre where a user can develop their thinking power, communication ability and many more. In India, "Notebandi" occurred on $8^{\text {th }}$ November 2016, decision was taken by Honorable Prime Minister of India. It was the tough time for all in demonetization. To cope with tough time libraries can play active role by awaking the users as well as community also. They should take the more ideas of the people which are coming from different minds. Librarian and member of library could post those discussions with problem and solution on the Prime Minister's blog. These posts could help him to know the thinking of people and acceptance of people about their decisions. On the basis of those posts he was able to take decisions in the favor of all citizens. ${ }^{3}$ On $1^{\text {st }}$ December 2016 Mr. Prakash Javedkar launched "Vittiya 
Saksharta Abhiyan" in New Delhi. Mr. Narendra Modi appealed to youth in "Maan Ki Baat" for creating awareness among people about digital economy and cashless modes of transactions. Mr. Prakash Javedkar, who is a Union Minister of Human Resources Development appealed to the young students to come forward and join "Vittiya Saksharta Abhiyaan" to create awareness and motivate all people around them to use a digitalization enabled cashless economic system for transfer of funds. The Union Minister said at the video conference with all higher education institutions held at NIC headquarters, that the country was undergoing transformational shift towards digital economy and youth should not only the witness the change but also actively participate in it by becoming agents of change. He also launched a webpage where students can register themselves to give continuous feedback and suggestions on the initiative as well as upload the progress of their work. ${ }^{3}$

${ }^{4}$ If academic libraries are to fulfill their civic mission in the information age, the must find active ways to engage faculty and students in order to encourage their involvement in democratic discourse and community renewal. ${ }^{4}$ Librarians should also update their knowledge with current issues and must design the strategies to impart knowledge and information amongst the users to boost the value of library in front of users.

\section{DEMOCRACY V/S PUBLIC LIBRARIES}

The public libraries play an important role in community progress and to build up democratic system. It is a place where everyone can come without discrimination of age, race, sex, religion, language or social status. Public libraries provide free access to information to its users which are very important for the foundation of democracy. ${ }^{5}$ The public library - the local gateway to knowledge provides a basic infra for lifelong learning, independent decision- making and cultural development of the individual and social groups. It is a living force for education, culture and information, and as an essential agent for the fostering of peace and spiritual welfare through the minds of men and women. UNESCO therefore encourages national and local governments to support and actively engage in the development of public libraries. ${ }^{5}$ IFLA/UNESCO Public Library Manifesto (1994)

In the absence of library we cannot assume effective democracy because library is a hub of world's knowledge. To impart the knowledge and information to its users, libraries should organize "Literacy Programs" because it is a first step in the journey of democracy. The librarian can provide a well planned structure to literate the local community which will be strength the roots of democracy.

\section{CONCLUSION}

In a nut shell, Academic and public libraries can play a very important role in democracy by literatim the users. Both libraries are hub of knowledge and information which provide education for a democratic society on the basis of equality. Activating opportunities in the libraries provide access to the ideas of users which facilitate them to think in different way. Mature thinking is a product of continuous learning. Learning is a lifelong process to compete with modern era. Libraries provide us a good platform to lifelong learning and to make a good citizen of nation.

\section{REFERENCES}

[1] Ranganathan, S.R, New Education and School Library (Vikas, 1973).

[2] Quotes libraries about and democracy. www.ala.org/aboutala/goverance/officers/past/kranich/demo/quotes.

[3] Competition success review, special January 2017 issue, Vol. LIII, No.7.

[4] Kranich, Nancy (2010) "Academic Libraries as Hubs for Deliberative Democracy, "Journal of Public Deliberation: Vol.6: Issue 1, Article 4. http:// www.publicdeliberation.net/jpd/vol6/iss1/art4

[5] http://www.ifla.org/files/assets/.../libraries.../public-libraries-brief.pdf 